\title{
GENETIC VARIATION \\ OF COWSLIP (PRIMULA VERIS L.) POPULATIONS (WEST POLAND)
}

\author{
MARIA MOROZOWSKA ${ }^{1}$, MARIA KRZAKOWA ${ }^{2}$ \\ ${ }^{1}$ Department of Botany, August Cieszkowski Agricultural University \\ Wojska Polskiego 71C, 60-625 Poznań, Poland \\ e-mail: mariamor@owl.au.poznan.pl \\ 2 Department of Genetics, Adam Mickiewicz University \\ Międzychodzka 5, 60-371 Poznań, Poland
}

(Received: January 29, 2003. Accepted: July 30, 2003)

\begin{abstract}
Genetic variation of twelve Polish populations of Primula veris L. from western Poland was investigated in respect of six enzyme systems: 6-phosphogluconate dehydrogenase (6PGD), diaphorase (DIA), menadione reductase (MNR), formate dehydrogenase (FDH), isocitrate dehydrogenase (IDH) and glutamate oxaloacetate transaminase (GOT). Only two of them (6PGD and DIA) were polymorphic and all populations were compared according to four loci and eight alleles. For 6PGD only one out of the two detected loci (locus 6PGD-2) was polymorphic and consisted of three alleles $a, b$ and $c$. For DIA each of two detected loci had two alleles. For 6PGD-2 one population was monomorphic and four populations were monomorphic for DIA-1 and DIA-2. The rest of the populations were polymorphic with low frequency of heterozygotes. The low heterozygosity level, found in the examined populations, was confirmed by high values of the fixation index $(F)$. The level of genetic differentiation among GST populations specified for each polymorphic loci, was equal to 0.045 for 6PGD-2 and had the value of 0.078 for DIA-2 and 0.186 for DIA-1. Nm value for polymorphic loci was 1.10 for DIA-1 and 2.94 for DIA-2, and for 6PGD-2 was 5.33, what indicates some gene flow between the examined populations. The dendrogram constructed on the basis of genotype frequencies showed that the populations were divided into two groups, however the most southern population No. 2 was clearly similar to the northern population No. 8 .
\end{abstract}

KEY WORDS: Primula veris, allozymes, genetic differentiation, gene flow.

\section{INTRODUCTION}

Genus Primula (Primulaceae) is composed of approximately 500 hundred species distributed throughout temperate regions of the northern hemisphere (Mabberley 1989; Valentine and Kress 1972). About hundred of them are European species, the rest grow mainly in Asia. In Poland it is represented by six species ( $P$. auricula L., $P$. minima L., $P$. farinosa L. - only one station, $P$. vulgaris Huds. - only one station, $P$. elatior L., $P$. veris) growing in natural stands, and two of them, $P$. elatior and $P$. veris are protected by low. Cowslip (Primula veris L.), which is the subject of our work, is common on almost all Polish lowlands and in lower localizations in the mountains (Mirek et al. 2002; Zając and Zając 2001). The species is a valuable, well-known pharmaceutical plant.

Since the genetic structure of cowslip natural populations was until now not examined in our country, not much is known about the genetic variation of the species in question. In England, it was found that both established and colonising cowslip populations had a very low level of genetic differentiation (Antrobus and Lack 1993). It is surprising, since cowslip, as a long-lived perennial and insect pollinated species, is heterostylous and obligate outcrosser (Tamm 1972; Lack 1982; Wedderburn and Richards 1990). The obligatory outcrossing system may cause differentiation and genetic diversity in natural populations when plants reproduce generatively. In case of the species in question, extending in size of cowslip populations is realised mainly through vegetative propagation (Tamm 1972; Morozowska 2000). Generative reproduction of $P$. veris plants also happens (Morozowska 1999; Kery et al. 2000). There is a belief that plants reproducing vegetatively are characterised by a lower level of diversity than plants reproducing generatively. However, some studies show that clonal plants have the same level of genetic variation as non-clonal ones (Ellstrand and Roose 1987).

The purpose of this study was to examine and determine the level of genetic variation among populations of Primula veris situated in western Poland. 


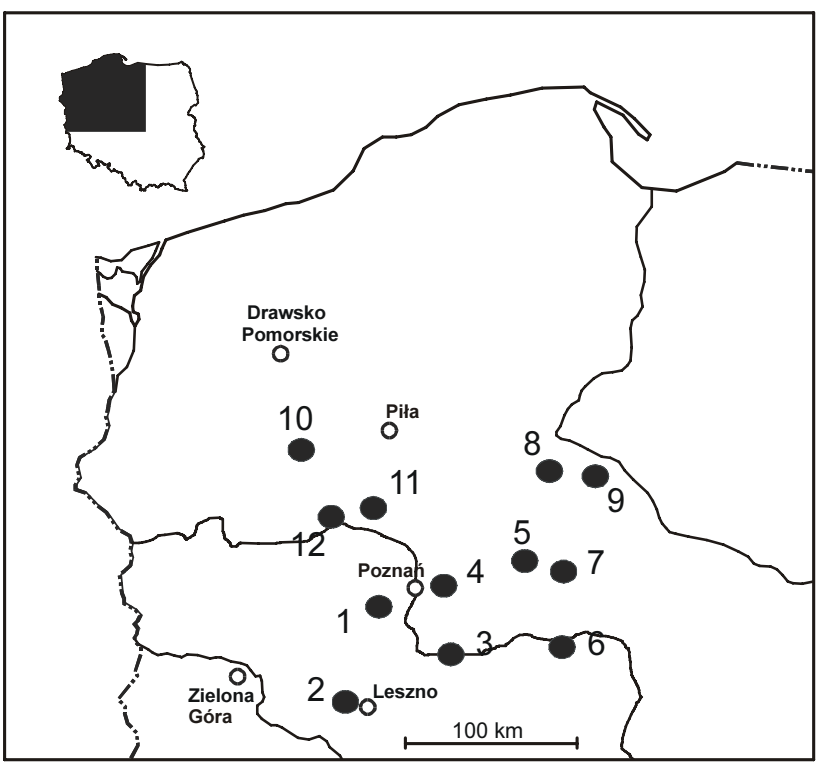

Fig. 1. Locations of twelve examined populations of Primula veris (as in Table 1); ( - localities and numbers of sampled populations; o - localities and names of cities in the examined region).

\section{MATERIAL AND METHODS}

\section{Plant material}

Twelve natural populations of P.veris from the western part of Poland were examined (Fig. 1). They differed in number of individuals and in size (Table 1). All populations were defined by a natural boundary and were located more than $50 \mathrm{~km}$ from one another. $P$. veris plants grew in different forest communities like ash-tree forest (Nos. 1, 2, 6), oak and beech-tree forest (Nos. 7, 8), mixed forest (Nos. 9, 12) or, in an exceptionally wet habitat as alder swamp (No. 10). In populations Nos. 3, 4, 5 and 11 the cowslip plants grew on grasslands.

Thirty individuals were sampled from each population. Young leaves were collected from randomly selected individual plants in early spring, before flowering, according to the transect system (sampled $1 \mathrm{~m}$ apart). Leaf samples were stored at $5^{\circ} \mathrm{C}$ for no longer than $48 \mathrm{~h}$ and then submitted to electophoresis.

\section{Electrophoresis procedure}

Leaf tissue was homogenised with $0.1 \mathrm{M}$ Tris/HCL $\mathrm{pH}$ 7.5 , mixed with $4 \mathrm{w} / \mathrm{v} \%$ polyvinylpyrrolidone (PVP). The electrophoresis was conducted horizontally in $11 \%$ starch

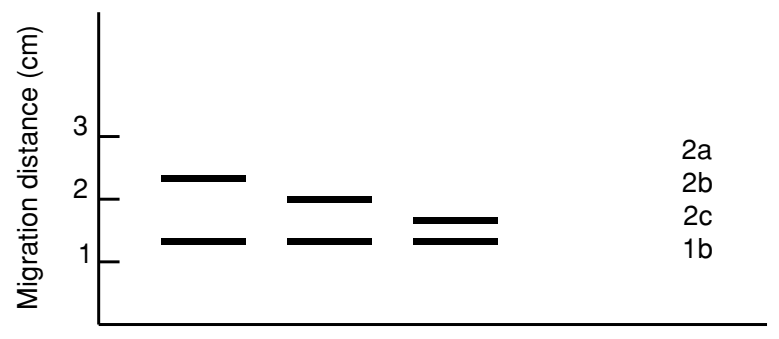

Fig. 2. 6PGD. Diagrams of allozyme band patterns of Primula veris.

gel (Sigma) under $150 \mathrm{~V}$ and $60 \mathrm{~mA}$, at $4^{\circ} \mathrm{C}$ for $5 \mathrm{~h}$. All populations were examined in respect of six following enzyme systems: 6-phosphogluconate dehydrogenase (6PGD), diaphorase (DIA), menadione reductase (MNR), formate dehydrogenase (FDH), isocitrate dehydrogenase (IDH), glutamate oxaloacetate transaminase (GOT).

\section{Data analysis}

The following genetic parameters such as: observed heterozygosity (Ho), expected heterozygosity $(\mathrm{He})$ and total genetic diversity $(\mathrm{Ht})$, fixation indices $(\mathrm{F})$, polymorphism indices of genotypes (Pg) according to Kahler et al. (1980), relative measure of genetic differentiation between populations (GST, DST) expressed by genetic similarities between populations based on gene frequency (Nei 1972), genotypes frequencies and genetic distances (Dh) (Hedrick 1974) were calculated.

\section{RESULTS}

Four of six examined enzyme systems (MNR, FDH, IDH and GOT) turned out to be completely monomorphic and therefore excluded from further comparisons. Our research was based on two polymorphic enzyme systems: 6PGD and DIA, in which four loci with eight alleles were identified. In 6PGD only one locus 6PGD-2, composed of three allozymes $a, b$ and $c$, was taken under consideration, since locus 6PGD-1 turned out to be monomorphic (Fig. 2). The most frequent in all populations was allele 6PGD-2 $c$, which in population No. 8 occurred as only one genotype $c c$. The rest of populations were polymorphic with low frequency of heterozygotes $a c$ and $b c$. Heterozygote $a b$ was not detected in our examinations (Table 2, 3). The most polymorphic were populations Nos. 1, 4 and 12 (Table 4).

TABLE 1. Locations and size of examined Primula veris populations.

\begin{tabular}{|c|c|c|}
\hline No. of population & Population (Locality) & Population size \\
\hline 1 & Wielkopolski National Park (S-W edge of Chomęcickie Lake) & $150 \mathrm{~m}^{2}$ \\
\hline 2 & Przemęcki Landscape Park (Forest Inspectorate Włoszakowice, Forest District Mścigniew, section 45) & $120 \mathrm{~m}^{2}$ \\
\hline 3 & Forest Inspectorate Jarocin, Forest District Potarzyca, section 323a & approx. $2500 \mathrm{~m}^{2}$ \\
\hline 4 & Lednicki Landscape Park (Ostrów Lednicki Island on Lednickie Lake) & approx. $600 \mathrm{~m}^{2}$ \\
\hline 5 & Kalina near Gniezno (N edge of Wierzbiczańskie Lake) & $450 \mathrm{~m}^{2}$ \\
\hline 6 & Nadwarciański Landscape Park (edge of Warta valley, E from Skokum) & $350 \mathrm{~m}^{2}$ \\
\hline 7 & Ostrów (Forest Inspectorate Miradz, Forest District Ostrowo, section 192) & $230 \mathrm{~m}^{2}$ \\
\hline 8 & Forest Inspectorate Solec Kujawski, Forest District Chrośna, section 14 & approx. $15600 \mathrm{~m}^{2}$ \\
\hline 9 & Forest Inspectorate Cierpiszewo, Forest District Ustronie, section 23 g & approx. $700 \mathrm{~m}^{2}$ \\
\hline 10 & Forest Inspectorate Głusko, Forest District Wołogoszcz, section 211 k, 231 b, c & $200 \mathrm{~m}^{2}$ \\
\hline 11 & Forest Inspectorate Krucz, Forest District Ciszkowo, section 501 & $150 \mathrm{~m}^{2}$ \\
\hline 12 & Forest Inspectorate Wronki, Forest District Kłodzisko, section 472 j & approx. $4000 \mathrm{~m}^{2}$ \\
\hline
\end{tabular}


TABLE 2. Allele frequencies of polymorphic loci in 12 examined Primula veris populations.

\begin{tabular}{|c|c|c|c|c|c|c|c|c|c|c|c|c|c|}
\hline \multicolumn{2}{|c|}{ Population number } & \multirow{2}{*}{1} & \multirow{2}{*}{2} & \multirow{2}{*}{3} & \multirow{2}{*}{4} & \multirow{2}{*}{5} & \multirow{2}{*}{6} & \multirow{2}{*}{7} & \multirow{2}{*}{8} & \multirow{2}{*}{9} & \multirow{2}{*}{10} & \multirow{2}{*}{11} & \multirow{2}{*}{12} \\
\hline Locus & Allele & & & & & & & & & & & & \\
\hline \multirow[t]{3}{*}{ 6PGD-2 } & $\mathrm{a}$ & 0.100 & 0.083 & 0.000 & 0.100 & 0.000 & 0.000 & 0.000 & 0.000 & 0.067 & 0.000 & 0.000 & 0.050 \\
\hline & $\mathrm{b}$ & 0.200 & 0.033 & 0.117 & 0.167 & 0.117 & 0.100 & 0.233 & 0.000 & 0.100 & 0.167 & 0.133 & 0.200 \\
\hline & $\mathrm{c}$ & 0.700 & 0.883 & 0.883 & 0.733 & 0.883 & 0.900 & 0.767 & 0.100 & 0.833 & 0.833 & 0.867 & 0.750 \\
\hline \multirow[t]{2}{*}{ DIA-1 } & $\mathrm{a}$ & 0.283 & 0.167 & 0.267 & 0.417 & 0.300 & 0.400 & 0.417 & 0.033 & 0.000 & 0.000 & 0.000 & 0.000 \\
\hline & $\mathrm{b}$ & 0.717 & 0.833 & 0.733 & 0.583 & 0.700 & 0.600 & 0.583 & 0.967 & 1.000 & 1.000 & 1.000 & 1.000 \\
\hline \multirow[t]{2}{*}{ DIA-2 } & $\mathrm{a}$ & 0.000 & 0.083 & 0.100 & 0.000 & 0.000 & 0.000 & 0.000 & 0.000 & 0.000 & 0.000 & 0.000 & 0.000 \\
\hline & $\mathrm{b}$ & 1.000 & 0.917 & 0.900 & 1.000 & 1.000 & 1.000 & 1.000 & 1.000 & 1.000 & 1.000 & 1.000 & 1.000 \\
\hline
\end{tabular}

TABLE 3. Genotype frequencies for twelve examined Primula veris populations.

\begin{tabular}{|c|c|c|c|c|c|c|c|c|c|c|c|c|c|}
\hline \multicolumn{2}{|c|}{ Population number } & \multirow{2}{*}{1} & \multirow{2}{*}{2} & \multirow{2}{*}{3} & \multirow{2}{*}{4} & \multirow{2}{*}{5} & \multirow{2}{*}{6} & \multirow{2}{*}{7} & \multirow{2}{*}{8} & \multirow{2}{*}{9} & \multirow{2}{*}{10} & \multirow{2}{*}{11} & \multirow{2}{*}{12} \\
\hline Locus & Genotype & & & & & & & & & & & & \\
\hline \multirow[t]{5}{*}{ 6PGD-2 } & aa & 0.100 & 0.000 & 0.000 & 0.100 & 0.000 & 0000 & 0.000 & 0.000 & 0.033 & 0.000 & 0.000 & 0.000 \\
\hline & $\mathrm{ac}$ & 0.000 & 0.167 & 0.000 & 0.000 & 0.000 & 0.000 & 0.000 & 0.000 & 0.067 & 0.000 & 0.000 & 0.100 \\
\hline & $\mathrm{bb}$ & 0.200 & 0.033 & 0.100 & 0.167 & 0.100 & 0.100 & 0.233 & 0.000 & 0.100 & 0.167 & 0.133 & 0.200 \\
\hline & $\mathrm{bc}$ & 0.000 & 0.000 & 0.033 & 0.000 & 0.033 & 0.000 & 0.000 & 0.000 & 0.000 & 0.000 & 0.000 & 0.000 \\
\hline & $\mathrm{cc}$ & 0.700 & 0.800 & 0.867 & 0.733 & 0.867 & 0.900 & 0.767 & 0.100 & 0.800 & 0.833 & 0.867 & 0.700 \\
\hline \multirow[t]{3}{*}{ DIA-1 } & aa & 0.233 & 0.133 & 0.233 & 0.333 & 0.267 & 0.333 & 0.333 & 0.033 & 0.000 & 0.000 & 0.000 & 0.000 \\
\hline & $a b$ & 0.100 & 0.067 & 0.067 & 0.167 & 0.067 & 0.133 & 0.167 & 0.000 & 0.000 & 0.000 & 0.000 & 0.000 \\
\hline & $\mathrm{bb}$ & 0.667 & 0.800 & 0.700 & 0.500 & 0.667 & 0.533 & 0.500 & 0.967 & 1.000 & 1.000 & 1.000 & 1.000 \\
\hline \multirow[t]{3}{*}{ DIA-2 } & aa & 0.000 & 0.067 & 0.067 & 0.000 & 0.000 & 0.000 & 0.000 & 0.000 & 0.000 & 0.000 & 0.000 & 0.000 \\
\hline & $a b$ & 0.000 & 0.033 & 0.067 & 0.000 & 0.000 & 0.000 & 0.000 & 0.000 & 0.000 & 0.000 & 0.000 & 0.000 \\
\hline & $\mathrm{bb}$ & 0.100 & 0.900 & 0.867 & 1.000 & 1.000 & 1.000 & 1.000 & 1.000 & 1.000 & 1.000 & 1.000 & 1.000 \\
\hline
\end{tabular}

TABLE 4. Genetic diversity estimates per locus among the examined Primula veris populations. He - expected heterozygosity; Ho - observed heterozygosity; F - fixation index; Pg - polymorphism index.

\begin{tabular}{|c|c|c|c|c|c|}
\hline Locus & Population no. & $\mathrm{He}$ & Ho & $\mathrm{F}$ & $\mathrm{Pg}$ \\
\hline 6PGD-2 & 1 & 0.4600 & 0.0000 & 1.000 & 0.4600 \\
\hline 6PGD-2 & 2 & 0.2117 & 0.1667 & 0.2126 & 0.3311 \\
\hline 6PGD-2 & 3 & 0.2061 & 0.0333 & 0.8383 & 0.2378 \\
\hline 6PGD-2 & 4 & 0.4244 & 0.0000 & 1.0000 & 0.4244 \\
\hline 6PGD-2 & 5 & 0.2061 & 0.0333 & 0.8383 & 0.2378 \\
\hline 6PGD-2 & 6 & 0.1800 & 0.0000 & 1.0000 & 0.1800 \\
\hline 6PGD-2 & 7 & 0.3578 & 0.0000 & 1.0000 & 0.3578 \\
\hline 6PGD-2 & 9 & 0.2911 & 0.0667 & 0.7710 & 0.3444 \\
\hline 6PGD-2 & 10 & 0.2778 & 0.0000 & 1.0000 & 0.2778 \\
\hline 6PGD-2 & 11 & 0.2311 & 0.0000 & 1.0000 & 0.2311 \\
\hline 6PGD-2 & 12 & 0.3950 & 0.1000 & 0.7468 & 0.4600 \\
\hline DIA-1 & 1 & 0.4061 & 0.1000 & 0.7538 & 0.4911 \\
\hline DIA-1 & 2 & 0.2778 & 0.0667 & 0.7600 & 0.3378 \\
\hline DIA-1 & 3 & 0.3911 & 0.0667 & 0.8295 & 0.4511 \\
\hline DIA-1 & 4 & 0.4861 & 0.1667 & 0.6571 & 0.6111 \\
\hline DIA-1 & 5 & 0.4200 & 0.0667 & 0.8413 & 0.4800 \\
\hline DIA-1 & 6 & 0.4800 & 0.1333 & 0.7222 & 0.5867 \\
\hline DIA-1 & 7 & 0.4861 & 0.1667 & 0.6571 & 0.6111 \\
\hline DIA-1 & 8 & 0.0644 & 0.0000 & 1.0000 & 0.0644 \\
\hline DIA-2 & 2 & 0.1528 & 0.0333 & 0.7818 & 0.1844 \\
\hline DIA-2 & 3 & 0.1800 & 0.0667 & 0.6296 & 0.2400 \\
\hline
\end{tabular}

DIA, examined in $P$. veris for the first time in this paper, had two electroforetically detected loci (DIA-1 and DIA-2) composed of the two alleles (Fig. 3). Four examined populations (Nos. 9-12) were monomorphic according to genotypes $1 b 1 b$ and $2 b 2 b$, and seven populations (Nos. 1-7) were polymorphic with low frequency of the heterozygotes $1 a 1 b$. Heterozygote $2 a 2 b$ was very rare and detected only in two populations No. 2 and No. 3. In these two populations all types of genotypes were detected, but again the most frequent were two of them $1 b 1 b$ and $2 b 2 b$ (Table 3). Populations Nos. 4, 6 and 7 proved to be the most polymorphic (Table 4). The examined populations were charac-

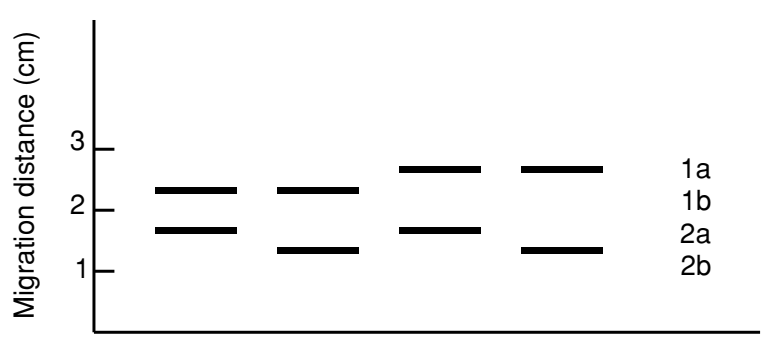

Fig. 3. DIA. Zymograms with locus designation and allozyme numbers for two loci of Primula veris. 
TABLE 5. Genetic diversity estimates for examined Primula veris populations based on 6PGD locus 2, DIA locus 1 and DIA locus 2. He - expected heterozygosity; Ho - observed heterozygosity; F - fixation index; Pg - polymorphism index.

\begin{tabular}{|c|c|c|c|c|}
\hline Population no & $\mathrm{He}$ & Ho & $\mathrm{F}$ & $\mathrm{Pg}$ \\
\hline 1 & 0.289 & 0.033 & 0.885 & 0.317 \\
\hline 2 & 0.214 & 0.089 & 0.584 & 0.284 \\
\hline 3 & 0.259 & 0.056 & 0.786 & 0.309 \\
\hline 4 & 0.304 & 0.056 & 0.817 & 0.345 \\
\hline 5 & 0.209 & 0.033 & 0.840 & 0.239 \\
\hline 6 & 0.220 & 0.044 & 0.798 & 0.256 \\
\hline 7 & 0.281 & 0.056 & 0.803 & 0.323 \\
\hline 8 & 0.022 & 0.000 & 1.000 & 0.022 \\
\hline 9 & 0.097 & 0.022 & 0.771 & 0.115 \\
\hline 10 & 0.093 & 0.000 & 1.000 & 0.093 \\
\hline 11 & 0.077 & 0.000 & 1.000 & 0.077 \\
\hline 12 & 0.132 & 0.033 & 0.747 & 0.153 \\
\hline Mean & 0.183 & 0.035 & 0.836 & 0.211 \\
\hline
\end{tabular}

TABLE 6. Genetic parameters estimating variation within and among examined populations of Primula veris. Ht - total genetic diversity; Hs - mean diversity within populations; DST - and GST - measures of genetic differentiation between populations; Nm - number of migrants per generation.

\begin{tabular}{cccccc}
\hline Locus & Ht & Hs & DST & GST & 0.045 \\
6PGD-2 & 0.283 & 0.270 & 0.013 & 5.33 & 0.186 \\
DIA-1 & 0.308 & 0.251 & 0.057 & 0.002 & 0.078 \\
DIA-2 & 0.030 & 0.028 & 0.024 & 0.116 \\
Mean & 0.207 & 0.183 & 1.94 & \\
\hline
\end{tabular}

terised by a low heterozygosity level $(\mathrm{Ho}=0.035)$, what was confirmed by high values of the fixation index $(\mathrm{F}=$ 0.836) (Table 5).

The level of genetic differentiation among populations GST (Hamrick and Godt 1990) specified for each polymorphic loci, had the value of 0.045 for 6PGD-2 and was equal to 0.078 for DIA-2 and 0.186 for DIA-1. Nm value for polymorphic loci was 1.10 for DIA-1 and 2.94 for DIA-2, and for 6PGD-2 was equal 5.33, what indicates some gene flow between the examined populations (Table 6).

The dendrogram constructed on the base of genotype frequencies showed that the examined populations were divided into two groups (Fig. 4). The first one was composed

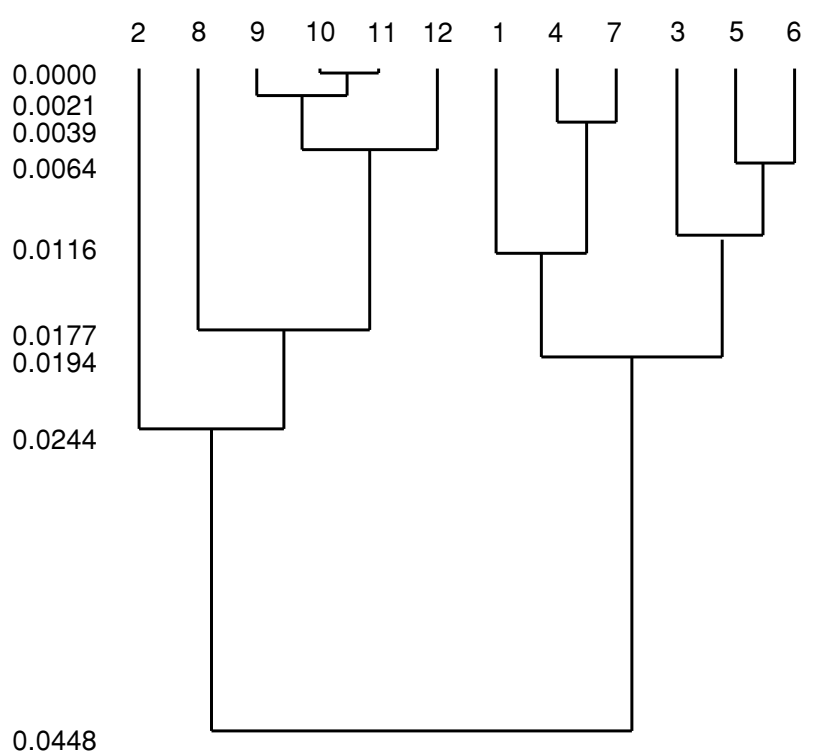

Fig. 4. Dendrogram illustrating the genetic similarities of Primula veris populations based on genotype distances (Dh), according to Hedrick (1974). of populations Nos. 2, 8-12, five of which (Nos. 8-12) were located on the north of the study region. The most southern population No. 2 was clearly similar to population No. 8 . The second group consisted of six south populations (Nos. 1, 3-7) (see Fig. 1). The values of genetic distances between populations were low, and the most similar were populations Nos. 10 and 11.

\section{DISCUSSION}

The results presented in this study indicate a very low level of genetic differentiation in natural populations of Primula veris, what is inconsistent with heterostyly and outcrossing typical for this species, as well as with its wide distribution in Europe. The examined populations showed differences in polymorphism level according to the examined enzyme systems. The most polymorphic were populations Nos. 1, 3, 4 and 7, and the lowest values of the polymorphism index Pg had populations Nos. 8, 10 and 11. Low level of polymorphism and genetic variation was found also for the closely related species Primula vulgaris (Cahalan and Gliddon 1985), and similar results were obtained from studies carried out in England in the established and colonizing $P$. veris populations (Antrobus and Lack 1993). The values of the Wright's fixation index (F) calculated for the examined by us populations were very high, often close to one. The F values calculated by Antrobus and Lack (1993) for P. veris populations in England were much lower (F value was less than 0.102) in comparison with the results obtained by us, and were even lower than F values reported by Brown (1979) for other insect pollinated outcrossing species. The high $\mathrm{F}$ values calculated for the examined here populations may result from the spatial distribution of individuals, especially in big populations were they had formed large clumps with a high number of flowering individuals, spatially separated from each other. 
That could result in fewer flights of pollinating insects between clumps than within them and cause a restricted gene flow. It is possible that the low level of heterozygosity found in the examined populations, may be the result of the obligatory cross pollination between plants with the same genotypes, according to the examined enzyme systems.

The low differentiation level among examined populations was confirmed by values of gene flow $(\mathrm{Nm})$. According to heterostyllic plants, gene flow with pollen depends on the amount of produced pollen, which is strongly influenced by differences between two flower morphs. Ornduff (1980) found out that the mean amount of the pollen produced by a single pin and thrum flower is like $2.4: 1$. The number of plants with pin and thrum flower morphs can differ in natural cowslip populations. Antrobus and Lack (1993) showed that the proportion of long- and short-styled morphs did not stray from 1:1 ratio. Kery et al. (2000) mentioned that deviations of the morph ratio from 1:1 have been found to be much larger in small than in large cowslip populations and reproduction in populations with large deviations was significantly reduced. Endels et al. (2002) studied 89 declining remnant populations of $P$. vulgaris and found a strong relationship between morph frequency and population size. Morph frequencies were equal (1:1) for large (>100 plants) and unequal for smaller populations. Very similar patterns have also been found for 18 populations of $P$. elatior (Jacquemyn et al. 2002). In our study the proportion of pin and thrum morphs was evaluated for three populations Nos. 4, 5 and 6. They consisted of over 500, 1200 and 1000 individuals, respectively. In population No. 4 there were $64 \%$ of plants with pin flowers and $36 \%$ with thrum flowers, in population No. 5 the proportion was like $1: 1$ and in population No. 6 there were $6 \%$ more plants with thrum flowers (Morozowska and Urbański 2000). The presence of flower morphs imbalance may lead to a lack of compatible pollen and may result in lowering the intensity of the generative reproduction. A further possible consequence may be low level of genetic differentiation in $P$. veris populations.

\section{LITERATURE CITED}

ANTROBUS S., LACK A.J. 1993. Genetics of colonizing and established populations of Primula veris. Heredity 71, 252-258 .

BROWN A.H.D. 1979. Enzyme Polimorphism in Plant Populations. Theoret. Popul. Biol., 15: 1-42.

CAHALAN C.M., GLIDDON C. 1985. Genetic neighbourhood sizes in Primula vulgaris. Heredity 54: 65-70.

ELLSTRAND N.C., ROOSE M.J. 1987. Patterns of genotypic diversity in clonal plant species. Am. J. Bot., 74: 123-131.

ENDELS P., JACQUEMYN H., BRYS R., HERMY M., de BLUST G. 2002. Temporal changes (1986-1999) in populations of primrose (Primula vulgaris Huds.) in an agricultural landscape and implications for conservation. Biological Conservation 105: 11-25.
HAMRICK J.L., GODT M.J. 1990. Allozyme diversity in plant species. In: A.H.D. Brown, M.T. Clegg, A.L. Kahler, B.S. Weir (eds), Plant Population Genetics, Breeding and Genetic Resources. Sinauer Associates Inc., MA, pp 43-63.

HEDRICK P.W. 1974. Genetic similarity and distance; comments and comparisons. Evolution 29, 362-366.

JACQUEMYN H., BRYS R., HERMY M. 2002. Patch occupancy, population size and reproductive success of a forest herb (Primula elatior) in fragmented landscape. Oecologia 130: 617-625.

KAHLER A.L, ALLARD R.W., KRZAKOWA M., WEHRHAN C.F., NEVO E. 1980. Associations between isozyme phenotypes and environment in the slender wild oat (Avena barbara) in Israel. Theo. Applied Genetics 56, 31-47.

KÉRY M., MATTHIES D., SPILLMAN H.H. 2000. Reduced fecundity and offspring performance in small populations of the declining grassland plants Primula veris and Gentiana lutea. Journal of Ecology 88, 17-30.

LACK A.J. 1982. The ecology of flowers of chalk grassland and their insect pollinators. Journal of Ecology 70, 773-790.

MABBERLEY D.J. 1989. The plant-book. A portable dictionary of the higher plants. Cambridge Univ. Press, Cambridge.

MIREK Z., PIĘKOŚ-MIRKOWA H., ZAJĄC A., ZAJĄC M. 2002. Flowering plants and pteridophytes of Poland. A checklist. - Krytyczna lista roślin naczyniowych Polski. W. Szafer Institute of Botany, Polish Academy of Sciences, Kraków (in Polish and English).

MOROZOWSKA M. 1999. Importance of studies on population biology for species protection of medicinal plants on an example of selected populations of cowslip (Primula veris L.). Rocz. AR Pozn., CCCX, Melior. Inż. Środ. 20, cz. II, 437-445.

MOROZOWSKA M. 2000. Charakterystyka ekologiczna naturalnych populacji Primula veris L. na Nizinie Wielkopolskiej. Rocz. AR Pozn., 322, Bot. 3, 165-173. (in Polish with English summary).

MOROZOWSKA M., URBAŃSKI Ł. 2000. Charakterystyka kwitnienia i owocowania oraz ocena produkcyjności nasiennej roślin pierwiosnka lekarskiego (Primula veris L.) z populacji zlokalizowanych na Nizinie Wielkopolskiej. Rocz. AR Pozn., 322, Bot. 3, 175-184. (in Polish with English summary).

NEI M. 1972. Genetic distance between populations. American Naturalist 106, 283-292.

ORNDUFF R. 1980. Pollen flow in Primula veris (Primulaceae). Pl. Syst. Evol., 135: 89-93.

TAMM C.O. 1972. Survival and flowering of perennial herbs III. The behaviour of Primula veris on permanent plots. Oikos 23, 159-166.

VALENTINE D.H., KRESS A. 1972. Primula L., In: T.G. Tutin, V.H. Heywood, N.A. Burges, D.M. Moore, D.H. Valentine, S.M. Walters, D.A.Webb (ed.), Flora Europaea. Band 3. Diapensiaceae to Myoporaceae. pp. 15-20, Cambridge Univ. Press.

WEDDERBURN F., RICHARDS A.J. 1990. Variation in within morph incompatibility sites in heteromorphic Primula L. New Phytologist 116, 149-162.

ZAJĄC A., ZAJĄC M. 2001. Atlas rozmieszczenia roślin naczyniowych w Polsce. Distribution Atlas of Vascular Plants in Poland. Prac. Chorol. Komp. Inst. Bot., Uniwersytet Jagielloński i Fundacja dla Uniwersytetu Jagiellońskiego, Kraków. (Lab. of Computer Chorology, Inst. of Bot. Jagiellonian University and Foundation of Jagiellonian University, Cracow), (in Polish and English). 


\section{ZRÓŻNICOWANIE GENETYCZNE \\ W POPULACJACH PIERWIOSNKA LEKARSKIEGO (PRIMULA VERIS L.) W POLSCE ZACHODNIEJ}

\section{STRESZCZENIE}

Przebadano poziom genetycznego zróżnicowania dwunastu populacji pierwiosnka lekarskiego (Primula veris L.) w Polsce Zachodniej, z wykorzystaniem sześciu systemów enzymatycznych: 6PGD, DIA, MNR, FDH, IDH i GOT. Tylko dwa z nich, 6PGD i DIA były polimorficzne i wszystkie populacje zostały porównane pod względem 4 loci i 8 alleli. Dla 6PGD, w obrębie dwóch wykrytych loci, tylko jeden locus (6PGD-2) był polimorficzny i składał się z trzech alleli $a, b$ i $c$. Dla DIA każdy z dwóch wykrytych loci składał się z dwóch alleli. W odniesieniu do 6PGD-2 jedna populacja okazała się monomorficzna, a w odniesieniu do DIA-1 i DIA-2 cztery populacje były monomorficzne. Pozostałe populacje były polimorficzne z niewielką frekwencją heterozygot. Stwierdzony niski poziom heterozygotyczności potwierdziły wysokie wartości współczynnika wsobności Wrighta (F). Poziom zróżnicowania genetycznego pomiędzy populacjami (GST) określony dla każdego z polimorficznych loci miał wartość 0,045 dla 6PGD-2 i wyniósł 0,078 dla DIA-2 oraz 0,186 dla DIA-1. Wartości Nm dla loci polimorficznych wyniosły 1,10 dla DIA-1, 2,94 dla DIA-2 oraz 5,33 dla 6PGD-2, co wskazuje na znaczny przepływ genów między populacjami. Dendrogram skonstruowany na podstawie częstości genotypów (Hedrick 1974) sugeruje istnienie dwóch grup w obrębie badanych populacji, jednakże najbardziej południowa populacja nr 2 jest wyraźnie podobna do populacji nr 8 znajdującej się w północnej części badanego regionu.

SŁOWA KLUCZOWE: Primula veris, allozymy, zróżnicowanie genetyczne, przepływ genów. 